\title{
Merancang Ulang Manual Material Handling Troli Kursi Ergonomis Untuk Mengurangi Tingkat Keluhan Rasa Sakit dan Meningkatkan Produktivitas Kerja Karyawan Banquet (Studi Kasus : Hotel Aryaduta Pekanbaru)
}

\author{
Anwardi $^{1}$, Ekie Gilang Permata ${ }^{2}$, Nofirza ${ }^{3}$, Harpito $^{4}$ \\ Dosen Jurusan Teknik Industri, Fakultas Sains dan Teknologi, UIN Sultan Syarif Kasim Riau \\ Jl. HR. Soebrantas No.155 Simpang Baru, Panam, Pekanbaru, 28293
}

\begin{abstract}
Abstrak
Keselamatan dan kenyamanan dalam berkerja merupakan hal yang paling terpenting bagi karyawan departement banquet terlebih sebuah hotel berbintang yaitu Aryaduta Pekanbaru. Karyawan banquet selama ini bekerja sering mengalami rasa nyeri dan sakit pada anggota bagian tubuh diantaranya bagian bahu dan tangan yang disebakan ketika karyawan membawa tumpukan kursi yang berjumlah 10 kursi yang memiliki berat sekitar $40 \mathrm{~kg}$ untuk perlengkapan acara dengan menggunkan troli kursi yang tidak ergonomi dari stotre barang ke grandball room yang memiliki jarak sekitar 60 meter. Penerapan perancangan ulang troli kursi yang ergonomi untuk mengurangi tingkat keluhan rasa sakit dan meningkatkan produktivitas kerja karyawan banquet di Hotel Aryaduta dengan menggunakan data antropometri dan untuk mengukur kelehan dengan menggunakan metode \%CVL, lebih ergonomis dari kondisi awal dimana persentase keluhan tidak nyaman karyawan sebelum perancangan sebesar $69,04 \%$ sedangkan setelah perancangan sebesar $8,33 \%$. Setelah perancangan terjadi penurunan denyut nadi karyawan pada \%CVL sebesar 3,08\% dan waktu baku yang didapat setelah perancangan sebesar 2,92 menit yang dimana sebelum perancangan sebesar 3,51 menit. Peningkatan Produktivitas kerja karyawan setelah perancangan dalam memabawa tumpukan kursi sebesar $20,58 \%$ yang dimana rata-rata setiap karyawan banquet dapat membawa tumpukam kursi sebanyak 21 tumpuk/ jam yang dimana sebelumnya dengan menggunakan troli kursi lama membawa tumpukkan kursi sebanyak 17 tumpuk/jam.
\end{abstract}

Kata Kunci: Antropometri, Nordic Body Map dan $\% C V$ 


\section{Pendahuluan}

Perancang selalu membuat inovasi dari produk-produk yang ada sehingga memudahkan penggunanya dalam melakukan pekerjaannya, namun saat ini banyak sekali dijumpai industriindustri yang masih menggunakan tenaga manusia untuk melakukan pekerjaan tertentu, salah satunya yaitu pekerjaan mengangkat dan membawa beban secara manual atau yang biasa disebut dengan manual handling. Menurut Pratiwi, dkk 2105, menyatakan bahwa aktifitas mengangkat, memindahkan, mendorong, manarik, membawa, atau menahan objek dengan menggunakan tenaga otot merupakan aktivitas dari manual material handling. Kenyamanan dari pekerja sudah terbukti sangat menunjang tingkat produktivitas pekerja, dengan demikian para penanggung jawab keselamatan dan kesehatan kerja harus memikirkan faktor-faktor kecelakaan kerja apabila tidak dilakukan dengan efektif, nyaman, aman, sehat dan efisien.

HotelAryaduta

Pekanbaru menyediakan jasa dalam bentuk akomodasi penginapan, restoran, penyelenggaraan acara (event) dan fasilitas lainya dalam hotel untuk umum yang memenuhi syarat kenyamanan dan bertujuan komersil dalam jasa. Hotel Aryaduta memiliki salah satu departemen yaitu departemen banquet. Peran dan fungsi departemen banquet adalah bertugas untuk mempersiapkan dan melayani acara seperti pesta, rapat, seminar dan lain-lain. Karyawan departemen banquet dituntut untuk melakukan pelayanan secara optimal untuk memenuhi kepuasan pengunjung.

Tabel 1 Data Jumlah Acara (Event) Hotel Aryaduta Pekanbaru

\begin{tabular}{|c|c|c|c|}
\hline No & Bulan (2017) & Jumlah Acara (Event) & Jumlah Pesanan \\
\hline 1 & Januari & 38 & 9800 \\
\hline 2 & Februari & 49 & 7904 \\
\hline 3 & Maret & 73 & 8650 \\
\hline 4 & April & 22 & 6620 \\
\hline \multicolumn{2}{|r|}{ Total } & 182 & 32974 \\
\hline
\end{tabular}

Dilihat dari Tabel 1 pengamatan yang diketahui dari tempat store barang dan ke tempat ruangan acara yang akan diselenggarakan tersebut terdapat masalah yang terlihat yaitu ketika karyawan banquet membawa 1 tumpukan yang berjumlah 10 kursi dengan menggunakan troli kursi yang dimana karyawan banquet membawa dengan menahan bobot kursi dengan berat 40 kilogram dan posisi troli yang dimiring supaya kaki kursi tidak mengenai lantai, disamping itu antara store barang ketempat ruangan acara yang akan diselenggarakan tidak berdekatan/satu ruang dan kondisi jalan yang dilewati mendaki/menurun menepuh jarak 60 meter. Hal ini menyebabkan adanya rasa tidak nyaman yang dialami pekerja setelah melakukan pekerjaan sehingga menimbulkan rasa sakit pada bagian tertentu.

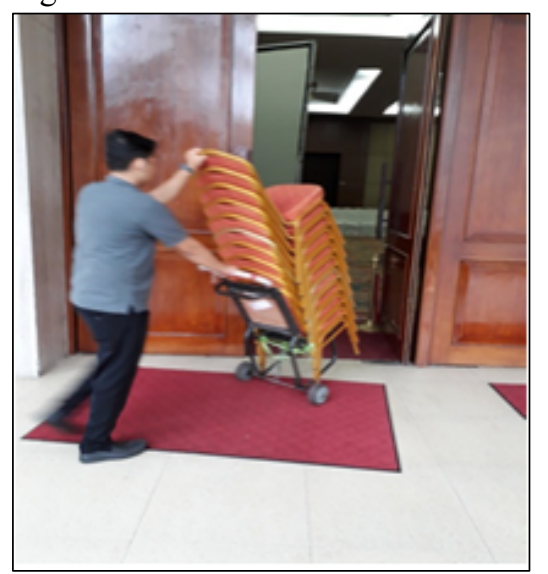

Gambar 1 Troli Kursi

Berdasarkan gambar 1 diatas observasi awal yang dilakukan, para karyawan banquet mengeluhkan bahwa mereka mengalami nyeri pada bagian bahu, lengan pergelangan dan tangan mereka. Kondisi seperti ini mereka keluhkan karena karyawan banquet membawa kursi dengan kondisi yang tidak nyaman. Adapun keluhan rasa sakit yang dirasakan oleh 6 orang karyawan banquet

Tabel 2 Persentase Keluahan Karyawan Banquet Hotel Aryaduta Pekanbaru

\begin{tabular}{|c|c|c|c|c|c|}
\hline \multirow{3}{*}{ No } & \multirow{3}{*}{ Jenis Keluhan } & \multicolumn{4}{|c|}{ Tingkat Keluhan } \\
\hline & & \multicolumn{2}{|c|}{ Tidak Sakit } & \multicolumn{2}{|c|}{ Sakit } \\
\hline & & Jumlah & 96 & Jumlah & 96 \\
\hline 0 & Salkit/kalu pada leber bagian ataq & 2 & 33,3 & 4 & 66,6 \\
\hline 1 & Salsit/kalk4 pada leher bagian bawah & 3 & 50 & 3 & 50 \\
\hline 2 & Salkit pada bahu kiri & - & - & 6 & 100 \\
\hline 3 & Salkit pada bahn banan & - & - & 6 & 100 \\
\hline 4 & Sakit padia lengan atas kiri & - & - & 6 & 100 \\
\hline 5 & Sakit padi pungeng & 1 & 16,6 & 5 & 83,3 \\
\hline 6 & Salkit pada lengan atas kanan & - & - & 6 & 100 \\
\hline 7 & Salsit pada pinggang & 2 & 33,3 & 4 & 66,6 \\
\hline 8 & Salkit pada bolkong & 5 & 83,3 & 1 & 16,6 \\
\hline 9 & Salkit padia pantat & 5 & 83,3 & 1 & 16,6 \\
\hline 10 & Salkit pada siku kiri & - & - & 6 & 100 \\
\hline 11 & Salkit pada silu kanan & - & - & 6 & 100 \\
\hline 12 & Salkit pada lengan barrah kiri & - & - & 6 & 100 \\
\hline 13 & Salkit pada lengan bawsah kanan & - & - & 6 & 100 \\
\hline 14 & Salkit pada pergelangan tangan kiri & - & - & 6 & 100 \\
\hline 15 & Salkit pada pergelangan tangan banan & - & - & 6 & 100 \\
\hline 16 & Salkit pada tangan kiri & - & - & 6 & 100 \\
\hline 17 & Salkit pada tangan kanan & - & - & 6 & 100 \\
\hline 18 & Sakit pada paha kiri & - & - & 6 & 100 \\
\hline 19 & Salkit pada paha banan & - & - & 6 & 100 \\
\hline 20 & Sakit pada lutut kiri & 6 & 100 & - & - \\
\hline 21 & Salkit padia lutut kanan & 6 & 100 & - & - \\
\hline 22 & Salkit pada batia kiri & 4 & 66,6 & 2 & 33,3 \\
\hline 23 & Salkit pada betia banen & 4 & 66,6 & 2 & 33,3 \\
\hline 24 & Sakit pada pergalangan kalki kiri & 3 & 50 & 3 & 50 \\
\hline 25 & Salkit pada pergelangan kaki kanan & 3 & 50 & 3 & 50 \\
\hline 26 & Sakit pada kaki kiri & 4 & 66,6 & 2 & 33,3 \\
\hline 27 & Salkit pada kaki kanan & 4 & 66,6 & 2 & 33,3 \\
\hline & Total & 52 & & 116 & \\
\hline
\end{tabular}


Berdasarkan tabel 2 diatas data kuesioner Nordic Body Map yang bernilai angka 69, $04 \%$ meberitahukan bahwa karyawan banquet merasakan nyeri/kesakitan saat melakukan aktivitas membawa kursi dari store barang ke tempat ruangan yang dituju terutama pada bagian bahu, punggung dan lengan, oleh karena itu perlu adanya perbaikan pada aktivitas saat membawa kursi menggunakan alat bantu troli.

Peracangan alat troli kursi ni diharapkan dapat mengurangi resiko pekerjaan yang ditibulkan dan memudahkan karyawan banquet dalam mempersiapakan segala kebutuhan acara yang akan diselenggarakan. Menurut penelitian dari Purnomo (2010) bahwa evaluasi yang dilakukan terhadap manual material handling yang akan digunakan pada troli rancangan penggunaan roda depan yang berpengunci sehingga dapat mengurangi beban vertikal saat menjalankan troli sehingga pekerja tidak ada merasakan nyeri/sakit pada bagian tubuh dan pekerja tidak mengalami kesulitan saat menyusun susunan tabung ke dalam troli, sehingga aktivitas bekerja lebih nyaman dan efisien serta waktu pekerjaan lebih optimal. Maka perumusan masalahanya adalah melakukan perancang ulang manual material handling troli kursi yang ergonomis untuk mengurangi tingkat keluhan rasa sakit dan meningkatkan produktivitas kerja karyawan banquet Hotel Aryaduta Pekanbaru.

\section{Tinjauan Pustaka}

\section{Pengertian Manual Material Handling}

Akivitas manual material handling merupakan sebuah aktivitas memindahkan beban oleh tubuh secara manual dalam rentang waktu tertentu. Berbeda dengan pendapat di atas menurut Occupational Safety and Health Administration (OSHA) mengklasifikasikan kegiatan manual material handling menjadi lima yaitu (Suhardi, 2008).

1. Mengangkat/Menurunkan

(Lifting/Lowering)

2. Mendorong/Menarik (Push/Pull)

3. Memutar (Twisting)

4. Membawa (Carrying)

5. Menahan (Holding)

\section{Konsep Dasar Ergonomi}

Ergonomi atau ergonomic (bahasa inggrisnya) sebenarnya berasal dari kata Yunani yaitu Ergo yang berarti kerja dan Nomos yang berarti hukum. Dengan demikian ergonomi di maksudkan sebagai disiplin keilmuan yang mempelajari manusia dalam kaitannya dengan pekerjaannya (Wignjosoebroto, 2008).

Ergonomi merupakan satu upaya dalam bentuk ilmu, teknologi dan seni untuk menyerasikan peralatan, mesin pekerjaan, sistem, organisasi dan lingkungan dengan kemampuan, kebolehan dan batasan manusia sehingga tercapai suatu kondisi dan lingkungan yang sehat, aman, nyaman, efisien dan produktif, melalui pemanfaatan tubuh manusia secara maksimal dan optimal. Agar tercapai kondisi tersebut, seharusnya peralatan dan lingkungan dikondisikan sesuai dengan kemampuan dan keterbatasan manusia, buka sebaliknya manusia disesuaikan dengan alat.

Sesuai dengan pengertian ergonomi prinsip penting ergomomi yang selalu digunakan adalah prinsip fitting the task/to the man, ini berarti harus disesuaikan dengan kemampuan dan keterbatasan manusia. Berdasarkan prinsip tersebut maka sistem kerja dirancang dengan memperhatikan faktor-faktor yang menjadi kelebihan dan keterbatasan manusia sebagai pengguna maka diperoleh suatu rancangan sistem kerja yang berada didalam daerah kemampuan manusia. Di dalam ergonomi dibutuhkan studi tentang sistem dimana manusia, fasilitas kerja dan lingkungannya saling berinteraksi dengan tujuan utama yaitu Menyesuaikan suasana kerja dengan manusianya. Ergonomi disebut juga sebagai human factor.

\section{Antropometri}

Istilah antropometri berasal dari "anthro" yang berarti manusia dan "metri" yang berarti ukuran. Antropometri adalah pengetahuan yang menyangkut pengukuran tubuh manusia khususnya dimensi tubuh (Suhardi 2008). Antropometri secara luas akan digunakan sebagai pertimbangan-pertimbangan ergonomis dalam proses perancangan (design) produk maupun sistem kerja yang akan memerlukan interaksi manusia. Data antropometri yang berhasil diperoleh akan dihasilkan secara luan antara lain (Wignjosoebroto, 2008):

1. Perancangan areal kerja (work station, interior mobil, dll).

2. Perancangan peralatan kerja seperti mesin, equipment, peralatan (tools) dan sebagainya.

3. Perancangan produk-produk konsumtif seperti, pakaian, kursi/meja komputer, dll.

4. Perancangan lingkungan kerja fiik. 
Penilain Beban Kerja Berdasarkan Denyut Nadi Kerja

Denyut jantung atau denyut nadi digunakan untuk mengukur beban kerja dinamis seseorang sebagai manifestasi dari gerakan otot. Menurut (Grandjean 1998 dan Suyasning 1981 dikutip oleh Andriyanto dkk, 2012). Pengukuran denyut jantung dapat dilakukan dengan berbagai cara yaitu (Mutia, 2014):

1. Merasakan denyut jantung yang ada pada arteri radial pada pergelangan tangan.

2. Mendengarkan denyut jantung dengan stethoscope.

3. Menggunakan ECG (Electrocardiograph) yaitu mengukur signal elektrik yang diukur dari otot jantung pada permukaan kulit dada.

Menentukan klasifikasi beban kerja berdasarkan peningkatan denyut nadi kerja yang dibandingkan dengan denyut nadi maksimum karena beban kardiovaskuler (cardiovasculair load $=\%(C L)$ yang dihitung dengan rumus sebagai berikut (Tarwaka, 2004):

$\% \mathrm{CVI}=\frac{100 \times(\text { Denyut nadi kerja }- \text { Denyut Nadi Istirahat })}{\text { Denyut nadi maksimum }- \text { Denyut nadi istirahat }}$

\section{Waktu Baku}

Perhitungan waktu baku merupakan perhitungan waktu tidak langsung. Jika semua data yang didapat telah memiliki keseragaman yang dikehendaki, dan jumlahnya telah memenuhi tingkat-tingkat ketelitian serta keyakinan yang diinginkan, maka selanjutnya adalah mengolah data tersebut sehingga memberikan waktu baku.

Langkah-langkah untuk mendapatkan waktu baku dari data yang terkumpul adalah sebagai berikut (Raharjo, 2008):

1. Menghitung waktu siklus rata-rata (Ws) dengan:

$$
W s=\frac{\sum \mathrm{x}_{\mathrm{i}}}{\mathrm{N}}
$$

Dimana:

$\mathrm{X}_{\mathrm{i}} \quad=$ Waktu Pengamatan

$\mathrm{N}=$ Jumlah Pengamatan

2. Menghitung waktu normal (Wn) dengan

$$
W b=W n \times(1+\alpha)
$$

Dimana:

$$
\mathrm{P} \quad=\text { Faktor Penyesuaian }
$$$$
\text { Ws = Waktu Siklus Rata-rata }
$$

3. Menghitung waktu baku (Wb) dengan:

$$
W b=W n \times(1+\alpha)
$$

Dimana:

$\alpha=$ Faktor Kelonggaran
$W n=$ Waktu Normal

\section{Metodologi Penelitian}

Metodologi penelitian merupakan tahapan dari awal penelitian sampai akhir penelitian. Metodologi digunakan untuk mengarahkan dan mempermudah proses analisis dalam mencari solusi dan memecahkan masalah, serta merancang manajemen penelitian secara baik. Dengan mengikuti tahapan-tahapan metodologi penelitian ini, maka mutu dan isi dari penelitian ini akan lebih baik. Adapun tahapan penelitian dapat dilihat pada Gambar 3:

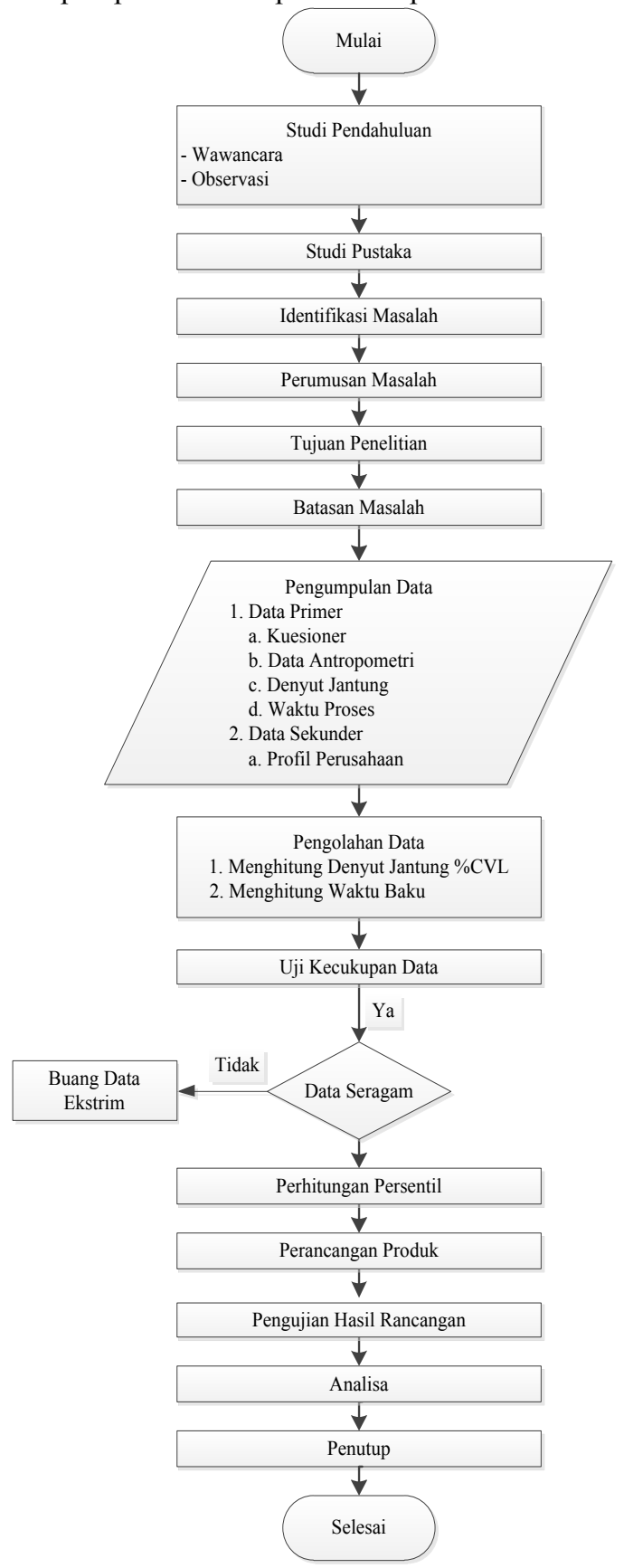

Gambar 1. Flowchart Penelitian 


\section{Hasil Penelitian}

\section{Denyut Nadi Sebelum dan Sesudah Perancangan}

Maka didapatkan hasil rekapitulasi beban kerja kayawan banquet saat melakukan pemindahan kursi. Adapun hasil rekapitulasi beban kerja kayawan banquet dapat dilihat pada table 3 dan 4:

Tabel 3 Rekapitulasi Data \%CVL Karyawan Banquet Sebelum Perancangan

\begin{tabular}{|c|c|c|c|c|c|c|c|}
\hline NO & Nama & Umur/Usia & DNK & DNI & $\mathbf{D N}_{\mathbf{m a x}}$ & $\mathbf{\% C V L}$ & Klasifikasi \\
\hline 1 & Firdaus & 30 Tahun & 118 & 78 & 190 & $35,71 \%$ & Diperlukan Perbaikan \\
\hline 2 & Zulfardi & 32 Tahun & 116 & 74 & 188 & $36,84 \%$ & Diperlukan Perbaikan \\
\hline 3 & Rusihan & 37 Tahun & 121 & 74 & 183 & $38,94 \%$ & Diperlukan Perbaikan \\
\hline 4 & Afdal D.H & 25 Tahun & 117 & 72 & 195 & $36,58 \%$ & Diperlukan Perbaikan \\
\hline 5 & Rasyid S & 26 Tahun & 121 & 70 & 194 & $41,12 \%$ & Diperlukan Perbaikan \\
\hline 6 & Rengga A.P & 20 Tahun & 120 & 71 & 200 & $37,98 \%$ & Diperlukan Perbaikan \\
\hline
\end{tabular}

(Sumber: Pengolahan Data 2017)

Tabel 4 Rekapitulasi Data \%CVL Karyawan Banquet Sestelah Perancangan

\begin{tabular}{|l|l|c|c|c|c|c|c|}
\hline NO & \multicolumn{1}{|c|}{ Nama } & Umur/Usia & DNK & DNI & $\mathbf{D N}_{\mathbf{m a x}}$ & $\mathbf{\% C V L}$ & Klasifikasi \\
\hline 1 & Firdaus & 30 Tahun & 113 & 73 & 190 & $43,18 \%$ & Diperlukan Perbaikan \\
\hline 2 & Zulfardi & 32 Tahun & 110 & 72 & 188 & $32,75 \%$ & Diperlukan Perbaikan \\
\hline 3 & Rusihan & 37 Tahun & 111 & 71 & 183 & $35,71 \%$ & Diperlukan Perbaikan \\
\hline 4 & Afdal D.H & 25 Tahun & 115 & 72 & 195 & $34,95 \%$ & Diperlukan Perbaikan \\
\hline 5 & Rasyid S & 26 Tahun & 114 & 68 & 194 & $36,50 \%$ & Diperlukan Perbaikan \\
\hline 6 & Rengga A.P & 20 Tahun & 115 & 70 & 200 & $34,61 \%$ & Diperlukan Perbaikan \\
\hline
\end{tabular}

(Sumber: Pengolahan Data 2018)

\section{Perhitungan Output Standra Sebelum dan Setelah Perancangan}

Untuk mengetahui output standar sebelum perancangan dari operasi ini, dilakukan perhitungan sebagai berikut:

$$
\begin{array}{ll}
\text { Total waktu pemindahan kursi } & =21,10 \text { menit } \\
\text { Jam kerja/hari } & =480 \text { menit } \\
\text { Output } \text { Standar } & =\frac{\text { Jam Kerja }}{\text { Waktu Baku }} \\
& =\frac{480}{3.51} \\
& =136.75=136 \text { Tumpukan kursi/hari } \\
& =\frac{136.75}{8 \text { jam }} \\
\text { Output } \text { Standar/Jam } & =17.09=17 \text { Tumpukan kursi/jam }
\end{array}
$$

Sedangkat intuk mengetahui output standar setelah perancangan dari operasi ini, dilakukan perhitungan sebagai berikut:

$\begin{array}{ll}\text { Total waktu pemindahan kursi } & =17,57 \text { menit } \\ \text { Jam kerja/hari } & =480 \text { menit } \\ \text { Output Standar } & =\frac{\text { Jam Kerja }}{\text { Waktu Baku }}\end{array}$


Output Standar/jam

$$
\begin{aligned}
& =\frac{480}{2,92} \\
& =164,38=164 \text { Tumpukan kursi/hari } \\
& =\frac{164,38}{8 \mathrm{jam}} \\
& =20,59=21 \text { Tumpukan kursi/jam }
\end{aligned}
$$

Analisa

\section{Data Antropometri dan Percentile Peracangan Ulang Troli Kursi Ergonomi}

Berikut ini merupakan data antropometri yang digunakan dalam perancangan ulang troli kursi ergonomi

Tabel 5 Dimensi Peracangan Ulang Troli

\begin{tabular}{|c|l|c|c|c|}
\hline No & \multicolumn{1}{|c|}{ Bagian Alat } & Ukuran & Antropometri & Percentile \\
\hline 1 & Tinggi troli ketika diberdirikan & $126 \mathrm{~cm}$ & Tbb & $50^{\text {th }}$ \\
\hline 2 & Tinggi troli ketika digunkan saat didorong & $95 \mathrm{~cm}$ & Tsb & $50^{\text {th }}$ \\
\hline 3 & Lebar pegangan (handle) sejajar troli kursi & $39 \mathrm{~cm}$ & Sks & $50^{\text {th }}$ \\
\hline 4 & Panjang pengangan (handle) troli kursi & $21 \mathrm{~cm}$ & Ltp & $95^{\text {th }}$ \\
\hline 5 & Diameter pegangan (handle) troli kursi & $28 \mathrm{~cm}$ & Pttj & $95^{\text {th }}$ \\
\hline
\end{tabular}

(Sumber: Pengolahanm Data 2018)

Berikut Ini adalah gambar rancangan ulang troli kursi ergonomi
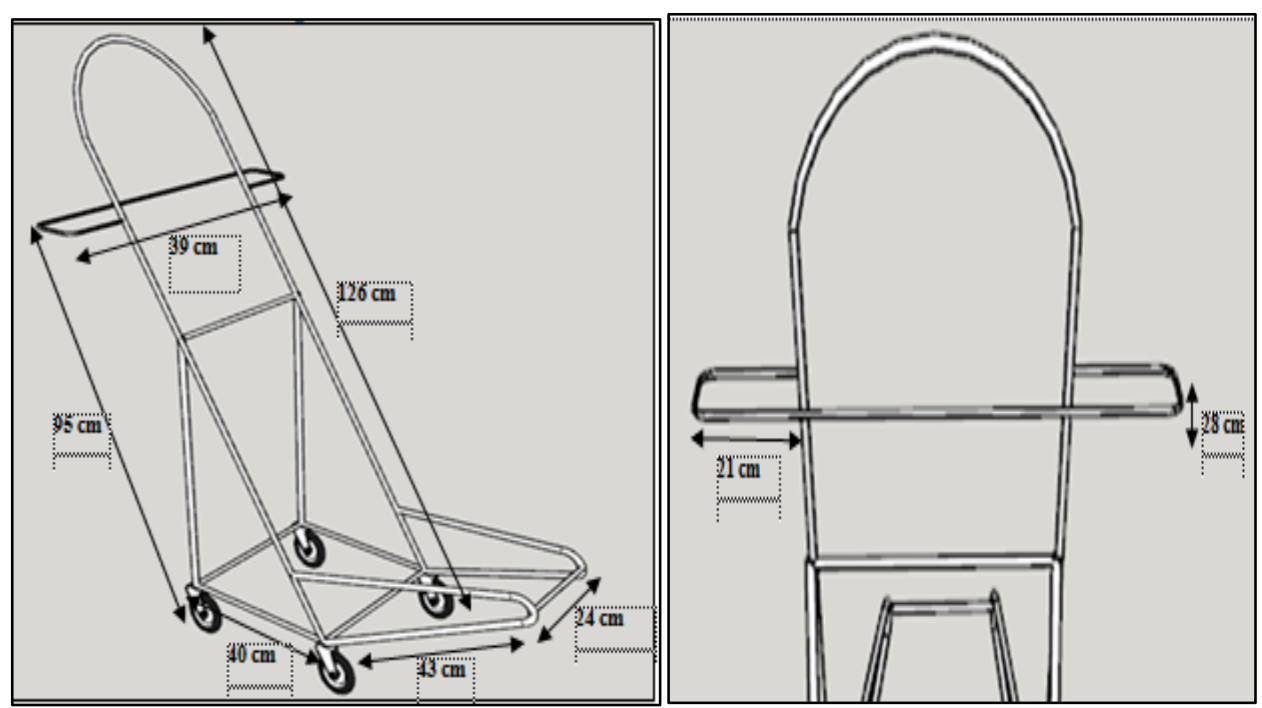

Gambar 2 Troli Kursi Ergonomi 


\section{Perbandingan Denyut Nadi Karyawan Hotel}

Data denyut nadi karyawan hotel didapat dari hasil pengumpula data untuk menentukan \%CVL pada karyawan hotel ketika. Berikut ini adalah perbandingan denyut nadi karyawan hotel saat menggunakan troli lama dan peracangan ulang troli kursi ergonomi.

Tabel 6 Perbandingan Denyut Nadi Troli Lama dan Peracangan Ulang Troli Kursi Ergonomi.

\begin{tabular}{|l|l|l|l|l|}
\hline No & Keterangan & $\begin{array}{l}\text { Troli Kursi } \\
\text { Lama }\end{array}$ & $\begin{array}{l}\text { Troli Kursi } \\
\text { Ergonomi }\end{array}$ & Perbadingan \\
\hline 1 & Denyut Nadi Kerja (DNK) & 118,83 & 113 & $5,83 \%$ \\
\hline 2 & $\%$ CVL & $37,86 \%$ & $34,78 \%$ & $3,08 \%$ \\
\hline
\end{tabular}

(Sumber: Hotel Aryaduta Pekanbaru, 2018)

Sedangkan rata-rata \%CVL (cardiovasculair load) nadi karyawan hotel stetelah seselesai bekerja menggunakan troli kursi lama saat membawa kursi sebesar $37,86 \%$ dan rata-rata \%CVL (cardiovasculair load) nadi karyawan hotel stetelah seselesai bekerja menggunakan perancangan ulang troli kursi ergonomi sebesar 34,78 \%. Artinya beban yang diterima tubuh menurun 3,08\% saat karyawan hotel menggunakan perancangan ulang troli kursi ergonomi.

\section{Perbandingan Waktu Kerja}

Berikut ini adalah perbandingan waktu baku aktivitas pemindahan kursi dengan menggunakan troli lama dan perancangan ulang troli kursi ergonomi adalah dapat dilihat pada tabel 5.2.

Tabel 7 Perbandingan Rata-rata Waktu Pemindahan Kursi

\begin{tabular}{|c|c|c|c|c|c|c|}
\hline Keterangan & Troli Lama & $\begin{array}{l}\text { Fakto } \\
\text { Penyesuaian }\end{array}$ & Allowance & $\begin{array}{l}\text { Troli } \\
\text { Perancangan }\end{array}$ & $\begin{array}{l}\text { Faktor } \\
\text { Penyesuaian }\end{array}$ & Allowance \\
\hline $\begin{array}{l}\text { Waku } \\
\text { Siklus }\end{array}$ & 2,23 menit & \multirow{3}{*}{1,16} & \multirow{3}{*}{$37 \%$} & 1,99 menit & \multirow{3}{*}{1.19} & \multirow{3}{*}{$28 \%$} \\
\hline $\begin{array}{l}\text { Waktu } \\
\text { Normal }\end{array}$ & 2,57 menit & & & 2,29 menit & & \\
\hline $\begin{array}{l}\text { Waktu } \\
\text { Baku }\end{array}$ & 3,51 menit & & & 2,92 menit & & \\
\hline
\end{tabular}

(Sumber: Hotel Aryaduta Pekanbaru, 2018)

\section{Perbandingan Produktuvitas Kerja}

Dalam menentukan besarnya produktivitas untuk penggunaan kondisi troli lama dan setelah perancangan ulang troli ergonomi dapat diketahui dengan output standar yang dihasilkan dan waktu kerja yang digunakan oleh karyawan hotel.

1. Troli Lama

Dalam 1 hari kerja selama 480 menit, waktu baku proses pemindahan kursi dengan menggunakan troli lama adalah sebesar 136 tumpukan kursi dan umtuk rata-rata setiap karyawan dapat membawa kursi sebanyak 17 tumpukan kursi/jam

2. Troli Peracangan Ulang Ergonomi

Dalam 1 hari kerja selama 480 menit, waktu baku proses pemindahan kursi dengan menggunakan troli lama adalah sebesar 164 tumpukan kursi dan umtuk rata-rata setiap karyawan dapat membawa kursi sebanyak 21 tumpukan kursi/jam

\section{Subjektivitas Karyawan Banquet}

Berikut ini adalah grafik keluhan rasa sakit karyawan dengan menggunkan kuesioner nordic body

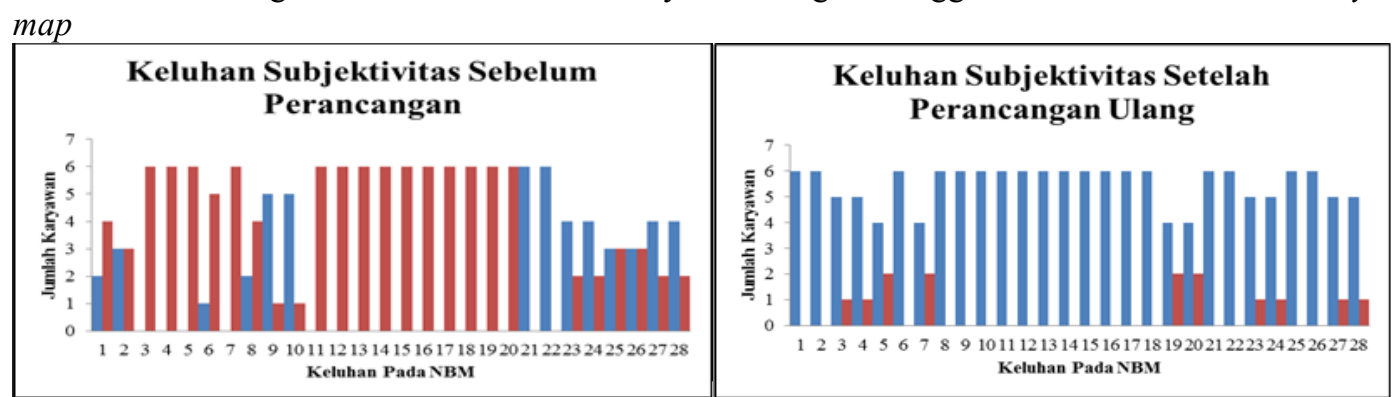

Gambar 3 Tingkat Keluhan Karyawan Banquet 


\section{Kesimpulan}

\section{Berdasarkan hasil penelitian} yang telah dilakukan, maka dapat disimpulkan bahwa perancangan ulang troli kursi ergonomi yang menggunakan data antropometri yang dibutuhkan adalah:

Tabel 8 Dimensi Peracangan Ulang Troli

\begin{tabular}{|c|l|c|c|c|}
\hline No & \multicolumn{1}{|c|}{ Bagian Alat } & Ukuran & Antropometri & Percentile \\
\hline 1 & Tinggi troli ketika diberdirikan & $126 \mathrm{~cm}$ & Tbb & $50^{\text {th }}$ \\
\hline 2 & $\begin{array}{l}\text { Tinggi troli ketika digunkan saat } \\
\text { didorong }\end{array}$ & $95 \mathrm{~cm}$ & Tsb & $50^{\text {th }}$ \\
\hline 3 & $\begin{array}{l}\text { Lebar pegangan (handle) sejajar } \\
\text { troli kursi }\end{array}$ & $39 \mathrm{~cm}$ & Sks & $50^{\text {th }}$ \\
\hline 4 & $\begin{array}{l}\text { Panjang pengangan (handle) troli } \\
\text { kursi }\end{array}$ & $21 \mathrm{~cm}$ & Ltp & $95^{\text {th }}$ \\
\hline 5 & $\begin{array}{l}\text { Diameter pegangan (handle) troli } \\
\text { kursi }\end{array}$ & $28 \mathrm{~cm}$ & Pttj & $95^{\text {th }}$ \\
\hline
\end{tabular}

(Sumber: Pengolahan Data 2018)

Aspek ergonomi yang didapat dari penelitian perancangan ulang troli kursi ergonomi dapat dilihat dari segi fisiologi kerjanya. Karyawan hotel yang menggunakan troli kursi lama rata-rata denyut nadinya sebesar 118,83 denyut/menit dan \%CVL 37,86 \%. Stelah melakukan perancangan ulang troli kursi ergonomi rata-rata denyut nadi karyawan sebesar 113 denyut/menit dan 34,78\%.

Dari tingkat keluhan rasa sakit yang diterima karyawan yang disebar melalui kuesinoner nordic body map mengalami penurunan, yang awal menggunakan troli lama sebesar $69,04 \%$ menurun menjadi $8,33 \%$ ketika menggunakan troli kursi ergonomi sehingga prduktivitas kerja karyawan meningkat sebesar 20,88\% dimana dalam 1 hari kerja karyawan rata-rata hotel dapat membawa 164 tumpukan kursi/hari dengan troli kursi ergonomi yang sebelum hanya dapat membawa rata-rata 136 tumpukan kursi/hari. Hal ini dapat menujukkan perancangan ulang troli kursi ergonomi membuat beban yang diterima tubuh menurun sehingga karyawan hotel menjadi lebih baik dari sebelumnnya.

\section{Daftar Pustaka}

[1] Andriyanto dan Choirul Bariyah. "Analisis Beban Kerja Operator Mesin Pemotong Batu Besar (Sirkel $160 \mathrm{Cm}$ ) dengan Menggunakan Metode 10 Denyut". Jurnal Teknik Industri Vol. 11 N0. 2, Universitas Andalas. Padang. 2012

[2] Astianto, Anggit dan Heru Suprihhadi. "Pengaruh Stres Kerja dan Beban Kerja Terhadap Kinerja Karyawan PDAM
Surabaya". Jurnal Manajemen Vol. 3 No.7, Sekolah Tinggi Ilmu Ekonomi Indonesia. Surabaya. 2014

[3] Christian, Lianawati, Angelina Permatasari dan Lianna Sugandi. "Sistem Informasi Perhotelan Front Office Menggunakan Metode Load Untuk Meningkatkan Pelayanan Customer: Studi Kasus PerhotelanOpen Source". Jurnal Sistem Informasi Vol. 4 No. 2, Univesitas Binus. Jakarta. 2013

[4] Juliatara, Birditha, Arie Desrianty dan Yuniar. "Analisis Tingkat Kelelahan Dan Kantuk Pada Pengemudi Bus X Berdasarkan Metode Objektif Dan Subjektif'. Jurnal Teknik Industri Vol. 03 No.02, Universitas Institut Teknologi Nasional. Bandung. 2015

[5] Kristanto, Agung dan Dianasa Adhi Saputra. "Perancangan Meja dan Kursi yang Ergonomis pada Stasiun Kerja Pemotongan Sebagai Upaya Peningkatan Produktivitas". Jurnal Ilmiah Teknik Industri Vol. 10 No. 2, Universitas Ahmad Dahlan. Yogyakarta. 2011

[6] Liliana, YP, Suharyo Widagdo dan Ahmad Abtokhi "Pertimbangan Antropometri Pada Pendisainan". Jurnal SDM Nuklir ISSN 1978-0176, Pusat Teknologi Reaktor dan Keselamatan Nuklir BATAN Kawasan Puspitek Serpong. Tangerang. 2007

[7] Mahmudi, Wildan Aziz dan Zahroh Za. "Peranan Kerjasama Team Antar Karyawan Banquet Guna Meningkatkan Pelayanan Out Let Banquet Pada Hotel Kartika Graha Malang (Study Pada Hotel Kartika Graha Malang)". Jurnal Administrasi Bisnis Vol. 21 No. 1, Universitas Brawijaya. Malang. 2015

[8] Mulyono, Eri, Ani Wijayanti dan Yulianto. "Peranan Banquet Event Order Dalam Meningkatkan Jumlah Tamu Pada Banquet Section Di Jogjakarta". Jurnal Khasanah Ilmu Vol. 4 No. 2, AKPAR BSI Yogyakarta. 2013

[9] Mutia, Mega., "Pengukuran Beban Kerja Fisiologis dan Psikologis Pada Operator Pemetik Teh dan Operator Produksi Teh Hijau di PT. Mitra Kerinci”. Jurnal Jurusan Teknik Industri Vol. 13 No.1, Uiversitas Andalas, Padang, 2014 
[10] Prasetyo, Eka Dan Agri Suwandi. "Rancangan Kursi Operator Yang Ergonomis Dengan Menggunakan Pendekatan Antropometri". Jurnal Teknik Mesin ISBN 978-602-19492-07, Universitas Pancasila. Jakarta. 2011

[11] Pratiwi, Hesti Meylia, Baju Widjasena dan Suroto. "Analisis Praktik Menggendong Pada Buruh Gendong Wanita di Pasar Induk Buah Pada Sayur Giwangan Kota Yogyakarta”. Jurnal Kesehatan Masyarakat Vol. 3 No. 2, Universitas Diponegoro. Semarang. 2015

[12] Putro, E. Perbaikan Rancangan Alat Pemotong Singkong Dengan Mekanisme Pedal Kaki Untuk Meningkatkan Produksi Dengan Prinsip Ergonomi. Tugas Akhir Jurusan Teknik Industri Universitas Sebelas Maret. Surakarta. 2009

[13 ']Raharjo, P. Usulan Perancangan Alat Pemotongan Kertas Karton. Tugas Akhir - Jurusan Teknik Industri Universitas Atma Jaya Yogyakarta. Yogyakarta. 2008

[14] Ruslan, Lalan Dan Nurfajriah, "Analisis Beban Kerja Fisiologi Dan Psikologi Karyawan Pembuatan Baju di PT Jaba Garmindo Majalengka”. Jurnal Teknik Industri Vol. 11 No. 2, Universitas Pembangunan Nasional. Jakarta. 2015

[15] Simanjuntak, Risma Adelina, Joko Susetyo dan Fitri Astiwahyuni. "Analisis Beban Kerja, Keluhan Muskuloskeletal, dan Kelelahan untuk Menentukan Kerja Lembur Pada Pt. Mega Andalan Kalasan”. Jurnal Teknik Industri, Institut Teknologi AKRIPRIND. Yogayakarta. 2013

[16] Suhardi, Bambang. "Perancangan Sistem Kerja dan Ergonomi Industri", Direktorat Pembinaan Sekolah Menengah Kejuruan. Jakarta, 2008

[17] Sukania, I Wayan, Lamto Widodo dan Desica Natalia. "Identifikasi Keluhan Biomekanik dan Kebutuhan Operator Proses Packing Di PT X". Jurnal Teknik Industri Vol. 6 No.1, Univeritas Tarumanegara. Jakarta. 2013

[18] Susetyo, Joko, Titin Isna Oes dan Suyasning Hastiko Indonesiani. "Prevalensi Keluhan Subyektif atau Kelelahan Karena Sikap Kerja yang Tidak Ergonomis pada Pengrajin Perak". Jurnal Teknik Industri Vol.1 No.2, Universitas Udayana. Bali. 2008
[19] Tarwaka, Solichul HA Bakri dan Lilik Sudiajeng. "Ergonomi untuk Keselamatan, Kesehatan Kerja dan Produktivitas". Uniba Press, Surakarta, 2004

[20] Wignjosoebroto, Sritomo. "Ergonomi", Guna Widya, Surabaya, 2008. 